\title{
無機顔料の表面処理 (II)
}

\author{
目次 \\ [第 1 報] \\ 1. 緒言 \\ 2. 特許公報に揭載された顔料の表面処理 \\ 3. 顔料の表面処理効果 (目的)
}

3.1 酸化チタンの表面活性

3.2 分散性向上

3.3 表面処理と耐久性

3.4 耐光性を目的とした表面処理

3.5 耐薬品性

3.6 耐熱性の向上

3.7 変色性の防止

3.8 その他

\section{4. 顔料の表面処理方法}

顔料は無機, 有機と,きわめて種類が多く,表面処理方 法は被表面処理物, 表面処理剤, 表面処理の目的等によ りそれぞれ異なり，きわめて多岐にわたる。同一構造を もつ顔料であっても製造方法の相違により，その表面処 理法もまたその効果も異なり，また同一処理剤を同じ顔 料について使用しても処理の方法により，顔料の表面の 性質は異なり処理効果も相違する等, 顔料の表面処理は きわめて複雑である。同一の顔料でも親油性にもなる し，また親水性に仕上げることも出来るなど，市販の顔 料は同一構造をるつものでも表面処理等により粉体工学 的物性, あるいは溶液系に使用する場合の界面化学的性 質など大いに異なるのが実情である。顔料の表面処理は 複雑であるが以下述べるような処理方法が，あるいはそ れらの組み合わせなどが現在行なわれている。

\section{1 湿式処理}

4.1.1 スラリー系で顔料粒子表面に沈着させる方法 実際行なわれている顔料の表面処理法の大部分は 3.5

前報 色材, 49 [1], 2 21（1976）

昭和 50.6.27 受理

Some Description on Surface Treatment of Inorganic Pigments (II)

Eiichi TSURUTA

* 古河鉱業(株)大阪工場

大阪市西淀川区大野 3 丁目 7 番 196 号
鶴田栄——

項で述べたようなこの湿式処理法によるものであり，被 表面処理顔料のスラリーを調製しておき，これに表面処 理剂を溶液の状態で添加し, 被処理顔料に吸着させる か, あるいは 3.5 項の例のように被表面処理顔料の表面 に化学反応により, 目的に応じて一種または二種以上の 処理剤の層を沈着させる方法がとられている。

工業的一例を酸化チタンについて述べると ${ }^{61)}$, 遠心口 ーラミル（主として Raymond Mill）で粉砕された焙焼 物 $\left(\mathrm{TiO}_{2}\right)$ は更に湿式ボールミル，あるいは振動ミルに かけられ，連続式横型遠心分離機を使用した分級が行な われ，粗大粒子を除去した適正粒子について 3.5 項で述 べたような方法で $\mathrm{Al}_{2} \mathrm{O}_{3}, \mathrm{SiO}_{2}, \mathrm{TiO}_{2}$ 等の含水物や媒 体への親和性などを考慮した有機物で酸化チタン粒子の 表面をかきまぜ機付の処理槽で被覆する。反応により生 成した不用の塩類などが出来上った製品中に残存しない ように十分水洗し，ロータリーフィルター，あるいはフ ィルタープレスで沪過し, バンド乾燥機等で乾燥し, 更 にエネルギーミルで仕上げの微粉砕を行なら方法がとら れている。

有機重合体物質の溶液中に顔料粒子を分散させて括 き，この溶液の極性を変化させることにより重合体成分 を顔料粒子上に沈殿させ被覆する方法 ${ }^{62)}$ が発表されてい る。たとえば非極性のポリブタジェン成分に対して該成 分から分岐した極性の側鎖として，メチルメタクリレー ト/メタクリル酸ランダム共重合体成分を結合してなる グラフト共重合体の溶液と, 酸化チタンをペブルミルで 混合粉砕する。次に取り出して高速混合器に入れミネラ ルスピリットを添加すると，グラフト共重合体成分は酸 化チタン粒子の表面に沈着し被覆する。この方法で黒色 顔料, 黄色顔料, アルミニウム等の実施例が述べられて いる。

分散性，粒子の大きさのコントロールを目的としたア ゾ顔料, フタロシアニン顔料等に一般的に行なわれてい るロジン処理方法も前記方法に類似している。すなわち 中性ないしアルカリ性懸濁液にロジンのアルカリ水溶液 を加え，これに塩化カルシウム，塩化バリウムなどの金 
属塩水溶液を加えることにより，ロジンのカルシウム 塩, バリウム塩などの金属塩として沈殿させ表面処理を 行ならすのである。またこのロジン処理に他の界面活性 剂を併用することなども行なわれている。

4.1 .2 高温高圧下で溶解度差により顔料表面に沈着 させる方法

信岡氏 ${ }^{63)}$ のケイ酸で顔料粒子の表面処理をする方法と して次のものがある。顔料を水または弱アルカリ性水溶 液中に分散させ，粒径 $2 \sim 3 \mathrm{~mm}$ ケイ砂を適当量添加す る。それをオートクレーブ中で $150 \sim 200^{\circ} \mathrm{C}$ 亿沶いて水 熱処理を行なら。そうすると添加されたケイ砂は温度の 上昇に伴って，溶解度を増し熱水に溶解する。所定温度 飞達した後放冷する。この水熱処理によって次のような 溶解析出反応が生起寸る。高温熱水に溶出したケイ酸塩 は最高温度に扔いて飽和状態であるが，冷却に伴って溶 解度が減少し余分のケイ酸が徐々に析出してくる。この 析出するケイ酸は, 顔料粒子の表面に薄層として析出す る。このようにして表面処理されるというもので, ベン ガラ, 酸化チダン, マンガン紫, カドミウム黄, 黄酸化 鉄などの実施例が述べられている。この表面処理により 耐久性, 耐薬品性, 変色性なぞが改良されることを述べ ている。

通常 $\mathrm{Al}_{2} \mathrm{O}_{3}, \mathrm{SiO}_{2}$ 等の湿式表面処理は常圧で行なる れ，顔料粒子の表面を含水物の状態で被覆しているが， 久保氏ら ${ }^{48)}$ は顔料を熱水中, 水可溶性の金属化合物之共 飞加熱加圧かきまぜ処理することにより，顔料の粒子表 面が金属化合物から誘導される金属酸化物の薄膜で被覆 され, きわめて耐光性, 耐熱性, 耐溶剂性, 耐薬品性等 の諸堅牢性に優れ，また分散性，着色力等においてる優 れた顔料を製造し得ることを述べている。

\section{2 乾式表面処理方法}

4.2.1 顔料の乾燥時または粉砕時に処理剤を添加す る方法

一例昼6を述べると酸化チタンに湿潤性を与える方法と して, 対酸化チタンで $0.1 \sim 1.0 \%$ のスチレン無水マレ イン酸共重合体で表面処理を行なう方法に，スチームマ イクロナイザーに移動するベルト上で所望の適当量をス プリンクーラーで顔料に供給し, 次いでスチームマイク ロナイザーにかける。あるいは乾燥機から出て来た処理 前の顔料に所望の適当量の表面処理剤を分散させ，20 30 分間ドラムローラーで混合し，スチームマイクロナ イザーにかけ粉砕を行ならものである。この処理の効果 は貯蔵中に形成される凝集体の数が少なくなる事及び㠜 集力が小さくなることから認められている。
4.2 .2 高温で表面処理剤を蒸気の状態で添加する方 法

塩素法酸化チタン，あるいは噴箮乾燥のような粉体の 流動工程を経るものについては，この方法は工業的に取 り組みやすい方法である。一例66を述べると四ハロゲン チタニウムを反応帯中で酸化ガスを用いて気相酸化する 二酸化チタン顔料を製造する方法に秥いて, 二酸化チタ ン顔料を含有するガス状流出物を気相反応帯から取り出 し，これにカリウム，ナトリウム，リチウム，セシウ ム，ルビジウム，バリウム，カルジウム，ストロンチウ ム，マグネシウム，亜鉛等蒸気金属イオンを供給する物 質を添加して接触させて生成した顔料の表面処理を行な い, 顔料の表面エネルギーを減少させるるのである。ま た 100 600 ${ }^{\circ} \mathrm{C}$ の流動層反応器に酸化チタンを流動させ て扣き，これに空気十水蒸気を送り込み，次いで空気を 次に金属拉よび非金属ハロゲン化物の蒸気を送り込及, このサイクルを繰返し，金属および非金属ハロゲン化物 の加水分解に上り顔料表面に被覆膜を形成するるのるあ る67)。このよらに交互処理で得られた被覆は4.1.1 で述 べたような湿式法で表面処理を施した場合よりも著しく 厚く, かつ強固であり, 而候性試験に打いて子優れた結 果が得られたが，これは湿式表面処理法に比して酸化物 の水和物被覆の構造がち密であることに基因するるのと 述べられている。

\section{3 混練する方法}

$\mathrm{Al}_{2} \mathrm{O}_{3}, \mathrm{SiO}_{2}$ 等の含水物による顔料の表面処理は溶液 系から顔料表面に反応析出させる方法をとっているが， 表面処理剤, 被処理顔料およびその目的などによっては 機械的に混練する方法などによっても効果を期待するこ とが出来る。丸茂氏 ${ }^{68}$ ) は表-2 亿記載 (特公昭 48-39213) の表面処理剂とグンジョウを混合し, 溶解混練して表面 処理顔料を調整している。これはポリスチレンの押出成 形品でよい分散状態を示している。また慶野氏ら ${ }^{69}$ は塗 料や印刷インキ用金色顔料の製造において，平均粒子径 $50 \mu$ の銅または銅合金粉末に, ニトロ基，八ロゲン基 またはアルコキシ基置換ベンジトリアゾールの微粉末を 混合かきまぜ処理することによって，防蝕防錆性および 耐熱性を付与している。

\section{4 固体表面（顔料表面）における化学反応により 処理する方法}

これは従来行なわれている顔料の表面処理と方法論に おいて異なり,ミクロな表面の物理化学的性質を積極的 に生かし, 固体表面に化学的に他の物質を反応させ結合 させて行くところに興味があり, 今後の研究が期待され る。 
4.4.1 R. Kroker 等の総説 ${ }^{70)}$

R. Kroker らは顔料表面に拈ける重合反応についての 総説を発表している。この総説から若干ピックアップし てみる。

（1）顔料表面が反応開始剂になる重合反応

顔料表面に反応開始を促進するグループがあるとポリ

マーがグラフトする。

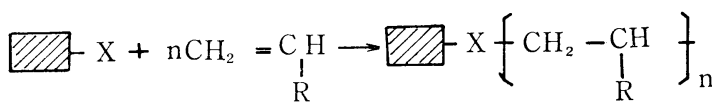

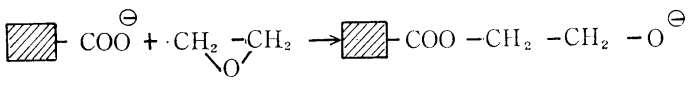<smiles>O=C(OCC[O+][O-])OCCC1CC2CCC1OOO2</smiles>

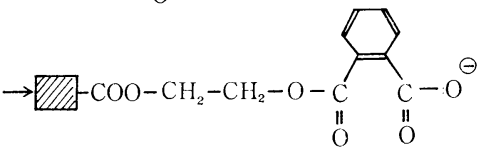

$\mathrm{SiO}_{2}$ 表面の反応は，

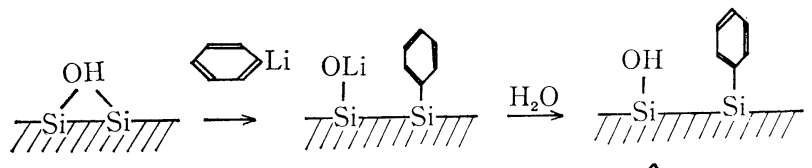

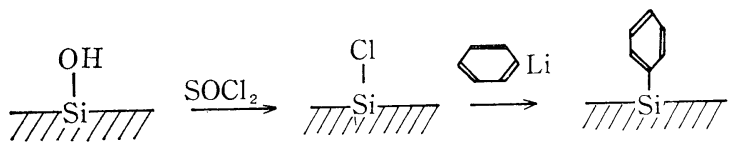

これはスチンン, アクリル酸，アクリルアミンやビニ ールピリジンなどのグラフトが可能であることを示して いる。

（2）顔料表面の重合可能基のホモまたは共重合

粉体表面に拈ける一般的反応パターンとしては次のよ らになる。

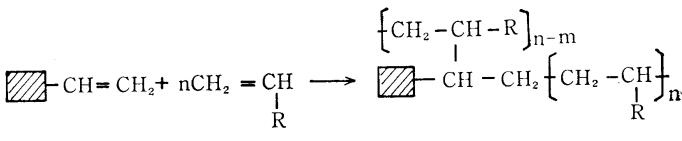

$\mathrm{TiO}_{2}$ にアクリル酸またはメタアクリル酸を吸着させ ると, その一部は不可逆層の形で表面に残る。この処理 顔料をスチレン中に分散して，BPO を開始剤として重 合するとポリスチレンができるが，同時に顔料表面に強 く結合したポリマー(アクリル酸/スチレン共重合体) む 得られる。その他いくつかの例が紹介されている。

(3) メカノケミカル過程による固体表面に拈ける重 合反応

重合能力のあるモノマー中で顔料を練摩すると, 生成 した顔料表面のラジカル位置で重合が開始する。例とし て，窒素中でスチレンとシリカをボールミル中で 練摩した。そしてシリカ表面に残った非抽出性ボ リマーは1\%のオーダーであり, そのシリカは強 い親油性を示した。同様な反応が $\alpha$-メチルスチ レン, アクリルニトリル，ブタジェン，クロロプ レンで認められている。その他酸化チタン, ベン トナイト, 炭酸カルシウムなども同様な研究が紹 介されている。しかし，今までのところメカノケ
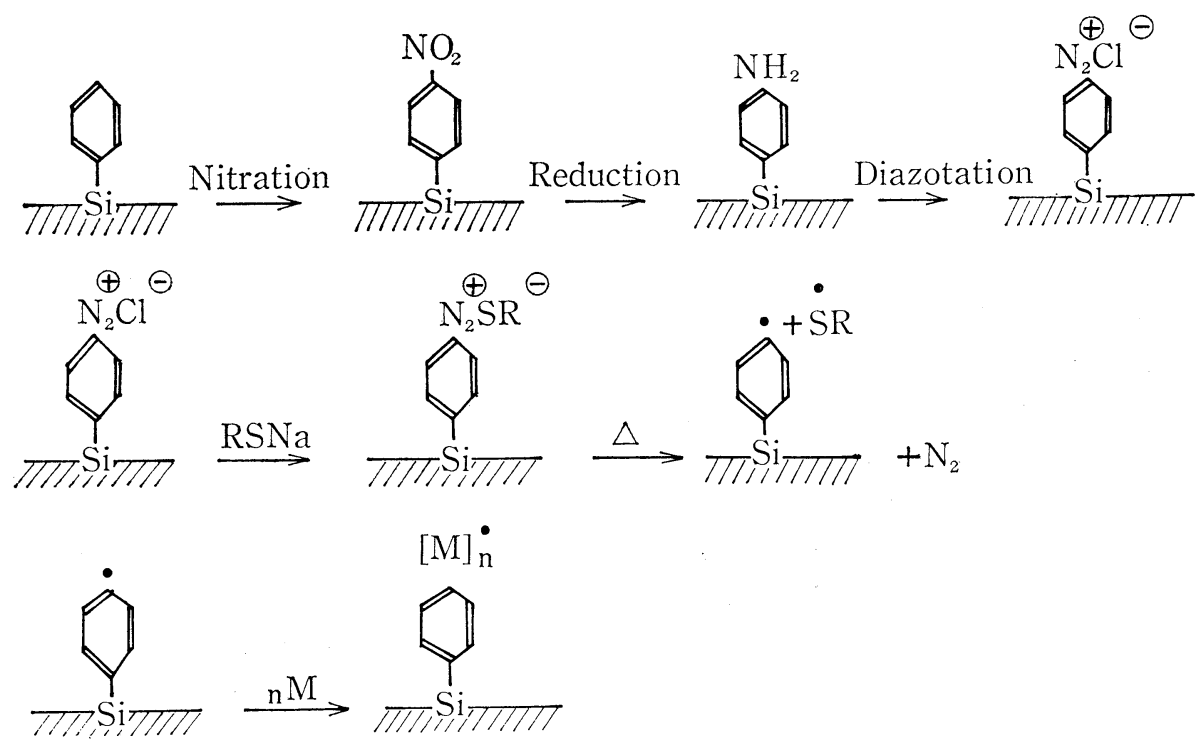
ミカル反応の立証はあまり明確でないが，長期間貯蔵後 も反応活性を示すことがメカノケミカル過程支持の論拠 となっている。

（4）高エネルギーによる固体表面での重合反応の開 始

シリカや活性炭の表面の炭化水素を $\beta$ 抢よび $\gamma$ 線で重 合し，ポリプロピレンが表面に単分子層から多分子層吸 着をしていることを認めている。これは沸騰キシレンで 抽出しても $2 \sim 4 \%$ の゚リプロピレンが残っている。同 様な実験をカーボンブラックや酸化マグネシウムの表面 飞高エネルギー電子線で, 塩化ビニル, メチルメタクリ レート，アクリルニトリルが生成する。その他の報告が 紹介されている。

なお，その他の報告がされているが結論として，顔料 表面における重合の反応機構は未だ十分解明されていな いが，このように顔料表面をポリマーで処理したものの 物性を，未処理顔料と対比して詳細に研究することは実 用上きわめて有意義であるとしている。

\subsection{2 堀内氏の研究 71)72) 73)}

堀内氏は顔料の分散性, 耐摩擦, 堅牢度等の向上を目 的として樹脂と色原体とを化学的に結合させることを考 え, 銅フタロシアニン系顔料について一連の報告をして いる。その一例をあげると銅フタロシアニン顔料あるい は低塩素化銅フタロシアニンのニトロ誘導体を合成し，

これを還元してアミノ銅フタロシアニンとし，さらにジ アゾ化し，そのジアゾ化合物をビニル単量体の存在下で 分解させることにより生じた銅フタロシアニンあるいは 低塩素化フタロシアニンラジカルが, ビニル単量体に重 合開始剤として作用し，これらの顔料色原体と結合した 有色重合物を得た。この有色重合物は抽出や分別沈殿を 行なっても分離することがなく，X 線回折，電子顕微 鏡，紫外，可視吸収スペクトルなどでその性質を調べ， その結果初期の目的の樹脂と色原体とを化学的に結合さ せた新しい銅フタロシアニン系の顔料であることを認め ている。これも類似点のある興味ある研究である。

\subsection{3 その他}

岡崎氏ら ${ }^{74)}$ は含水酸化チタン, アナタース形市販品を

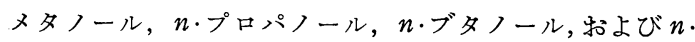
オクタノールとオートグレーブ中で $230^{\circ} \mathrm{C} \sim 280^{\circ} \mathrm{C}$ で反 応させ, 表面エステル化反応の進行度およびその効果を 調べている。その結果エステル化することにより親油性 を増し，長鎖アルコールほど表面被覆効果がすぐれ，乙 たがって親油性が大きくなることを認めている。

また宇津木氏ら ${ }^{75)}$ は直鎖飽和アルコール，芳香族アル コール，不飽和結合を有するアルコールおよび 2 価アル
コールのヘキサン溶液にシリカゲルを浸セキし，オート クレーブ中高温高圧下で反応し，ヘキサンの臨界点付近 で排気し，ついでアルコールまたはベンゼンおよびへキ サンで洗浄することにより, シリカゲルの表面処理を行 なった。その結果処理されたものは，

（1） 2 価アルコールおよび tert アルコール処理を 除き親油性である。

（2）元素分析およびアルゴン表面積とから付着基は アルコキシ基であること，および不飽和結合を有するア ルコール処理の場合も付着基の二重結合はそのままであ る。

（3） 2 価アルコールは一個の水酸基が表面シラノー ルと反応し $>\mathrm{Si}-\mathrm{O}-\mathrm{ROH}$ の結合を示し，処理シリカ表 面が水酸基で括和われるので親水性を示すこと。

（4）第三級アルコールは表面シラノールとは反応し ない。

（5）表面処理後のアルゴン表面積の減少は, 表面基 でおおおれたミクロ孔の存在にあるとして説明してい る。

\section{5. 顔料の表面処理と物理化学的性質}

顔料は前にも述べた通り, 顔料本来の目的で使用され る場合には塗料, インキ, 樹脂加工品（成型品）等いず れも他の媒体中に分散させて使用するものであり, 顔料 媒体系の相互作用についての界面化学的知見は, 生産工 学面に和ける実用的な見地からも重要であり, 理論的に も興味ある問題である。今塗料の製造を例にとると，ま ずビとクル中に顔料を投入して分散させるが，まず顔料 がそのビヒクルにぬれやすいことが作業性（作業能率） を左右するし，次の段階として顔料が塗料として要求さ れる粒度まで分散することが必要であり，出来上った塗 料は貯蔵安定性などが要求される。また使用される段 階，すなわち塗装時にハケさばきなどレオロジカルな性 質が適正であることが要求される。また溶液系の塗料, インキは塗膜の乾燥過程において時々刻々と溶液系の組 成は変化し, 最終的には乾燥した塗膜になるが, wet か ら dry のその過程で顔料は安定した分散状態を維持す ることが必要である。これら界面化学的問題は基本的に は次のことに要約される。

（1）顔料の分散媒に対する“ぬれ”の問題。

（2）分散媒中における顔料表面の荷電。

（3）顔料固体表面における溶媒, 溶質等の相互関 係，すなわち吸着現象など。

等があげられるが，これらの得られた情報を一つ一つ解 析することにより, 塗料, インキ等の溶液系に打ける諸 
特性を解明する手がかりが得られ，積極的に品質設計な ぞに意味があるものと思われる。

「顔料の表面処理と物理化学的性質」といら大きなテ 一マについて，筆者のよく述べつくせるものではない が, 顔料の表面処理について積極的展開を考兄る場合, きわめて大事な基礎的問題であり, 顔料工学的に有意義 であり技術的に興味ある問題である。幾つかの事例をあ げてその意義を考えてみたいと思う。

\section{1 表面処理と表面積}

表面処理をすることにより, 顔料の粉体物性, 溶液系 に打汗る界面化学的性質等が大さく変化することはこれ から述べるが，これらの現象は表面積の大学さが関与す ることを無視出来ない。また表面積は確かに一面におい て粉体の活性度の尺度である。一般に無機颜料の表面積 は 1 50 $\mathrm{m}^{2} / \mathrm{g}$ であり, 有機顔料では 10 100 $\mathrm{m}^{2} / \mathrm{g}$ で ある。カーボンブラックは $1,000 \mathrm{~m}^{2} / \mathrm{g}$ 程度のものもあ る。無機顔料に抢いては一般に $\mathrm{Al}_{2} \mathrm{O}_{3}, \mathrm{SiO}_{2}$ 等の含水 物で表面処理を施すことにより表面積は大きく増加の傾 向を示すが, 一, 二の例学表- $6^{44)}$, 表-7 ${ }^{76)}$ に示す。表-6 は酸化チタンについて $\mathrm{TiO}_{2}, \mathrm{Al}_{2} \mathrm{O}_{3}, \mathrm{SiO}_{2}$ の含水物によ り表面処理を行なったものの処理前後の表面積を示して 和り，大きな相違が認められる。D. Urwin ${ }^{44)}$ は表面処 理層の厚さは $50 \AA$ 程度であるから, 顔料粒子径の大き さは $100 \AA ̊$ の增加であり，これから表-6 のよらな表面 積の増加は考方られず, 表面処理層は多孔質であること を述べている。しかし, 䈌密には処理前後の両者の表面

表-6 酸化チタンの表面処理による表面積の変化

\begin{tabular}{c|c|c|c|c}
\hline \multirow{2}{*}{ 顔 料 } & \multirow{2}{*}{$\begin{array}{c}\text { 粒 子 径 } \\
(\mu)\end{array}$} & $\begin{array}{c}\text { 表 計 面 積 } \\
\left(\mathrm{m}^{2} \mathrm{~g}^{-1}\right)\end{array}$ & \multicolumn{2}{|c|}{ 表 面 積 (B. E. T) } \\
\cline { 4 - 5 } & $\begin{array}{c}\text { 未 処 理 } \\
\left(\mathrm{m}^{2} \mathrm{~g}^{-1}\right)\end{array}$ & $\begin{array}{c}\text { 処 理 } \\
\left(\mathrm{m}^{2} \mathrm{~g}^{-1}\right)\end{array}$ \\
\hline 1 & 0.21 & 6.8 & 7.2 & 13.8 \\
2 & 0.17 & 8.5 & 9.0 & 13.2 \\
3 & 0.22 & 6.5 & 7.1 & 14.2 \\
4 & 0.26 & 5.5 & 6.2 & 11.4 \\
\hline
\end{tabular}

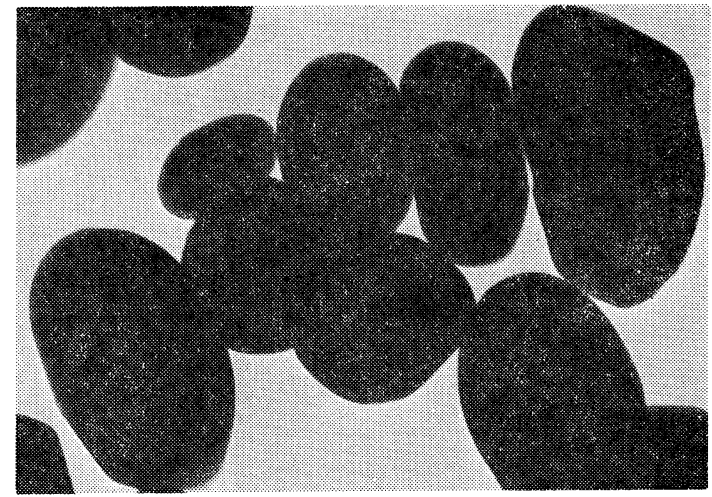

写真-4 表面処理なしのルチル形酸化チタン

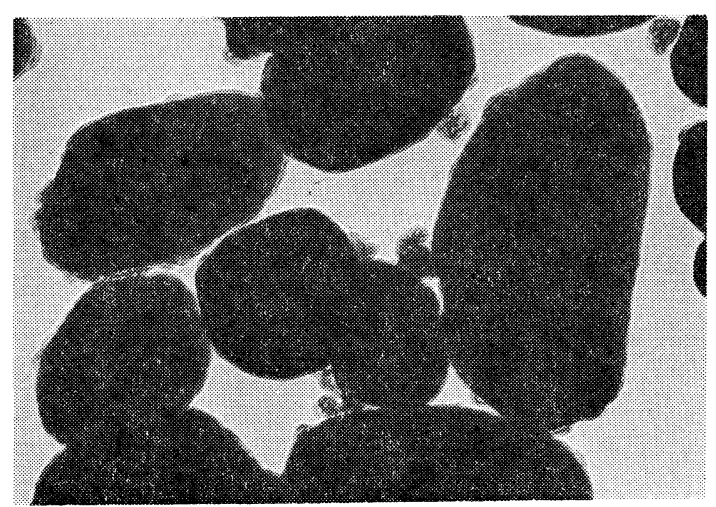

写真-5 $\mathrm{Al}_{2} \mathrm{O}_{3} \cdot n \mathrm{H}_{2} \mathrm{O}, \quad \mathrm{SiO}_{2} \cdot n \mathrm{H}_{2} \mathrm{O}$ の表面処理を 施したルチル形酸化チタン

積の相違は, 真に酸化チタン粒子の周囲に密着した処理 層が形成されたために增加したもののみか疑問はある。 実際表面処理したもの電子瀕微鏡で観察すると, 写真 -5のように酸化チタン粒子の表面に処理剤の強固な被 覆層を認めるが, 遊離の処理剤のゲル状に存在するもの も認められる(処理条件などによりこの状態は異なる)。 従って，それらが処理された酸化チタン顔料中にブレン ドされたような状態になっている。耐薬品性の項でも述 ベたように, 処理条件により被覆膜の状態も異なり, 顔

表-7 ルチル形酸化チタンの表面処理と表面積

\begin{tabular}{|c|c|c|c|c|c|c|c|c|c|}
\hline & \multirow{2}{*}{ 顔 } & \multirow{2}{*}{ 料 } & \multirow{2}{*}{$\mathrm{TiO}_{2}$} & 処 理 & $(\%)$ & \multirow{2}{*}{$\begin{array}{c}\text { 表面 積 } \\
\mathrm{m}^{2} \mathrm{~g}^{-1} \\
\operatorname{BET}^{\left(\mathrm{N}_{2}\right)}\end{array}$} & \multirow{2}{*}{$\begin{array}{c}\text { 水分の吸着 } \\
\mathrm{NoOH} / \\
100 \AA^{2}\end{array}$} & \multicolumn{2}{|c|}{ 表 面 積 } \\
\hline & & & & $\mathrm{SiO}_{2}$ & $\mathrm{Al}_{2} \mathrm{O}_{3}$ & & & $\mathrm{~S}_{\mathrm{H}_{2} \mathrm{O}}$ & $\mathrm{S}_{\mathrm{H}_{2} \mathrm{O}} / \mathrm{S}_{\mathrm{N}_{2}}$ \\
\hline A & 硫酸法 & & 99.9 & 0.044 & 0.014 & 5.6 & 1. 45 & 4. 49 & 0.76 \\
\hline B & "l & Aをべースとして処理 & 99.4 & 0.12 & 0.4 & 6.5 & 7.59 & 4.93 & 0.76 \\
\hline $\mathrm{C}$ & $\prime \prime$ & $\prime \prime$ & 97.1 & 0.04 & 2.5 & 13. 1 & 11.15 & 11.53 & 0.88 \\
\hline $\mathrm{D}$ & $\prime \prime$ & $\prime \prime$ & 96.8 & 0.9 & 2.3 & 10.6 & 13.94 & 10.58 & 0.99 \\
\hline $\mathrm{E}$ & $\prime \prime$ & "l & 92.8 & 5.4 & 2.3 & 31.3 & 8.53 & 16. 45 & 0.53 \\
\hline $\mathrm{F}$ & 塩素法 & & 96.1 & 0.1 & 3.8 & 13. 9 & 9. 95 & 11.93 & 0.86 \\
\hline
\end{tabular}


料工学的に興味ある問題である。遊離状態に市るゲル状 処理剂は顔料の表面処理の面のみから考えれば良い状態 ではないが，ゲル状に存在するものの含有量が多く，集 合体としての顔料の物性を大きく変える場合むあり，ま た商品としての評価を向上させることもある。

\section{2 表面処理と湿潤熱}

らどんやパンを作る場合にまず小麦粉を水で練るが， これは小麦粉と空気との固気界面が次第に消隇して, 新 たに小麦粉と水の界面 (固液界面)が生じる現象である。 小麦粉は始めのらちはなかなか䏓にくく水が玉になっ てしまら。塗料, インキ等はいずれる同じ現象であり,

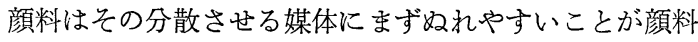
工学的に強く要求される。ぬれやすさ等固体表面の状態 を知る一つの情報源として湿潤熱があげられる。固体表 面の状態が不均一であっても表面の性質をよく描写して くれるといら意味で, 湿潤熱のもつ物理化学的意味は大 きいと思われる。1940 年代に W. D. Hakins らによって 測定が行なわれ，1950１960 年代に A.C. Zettlemoyer らの多くの研究が発表されている。この方面に関して, 森本氏 ${ }^{77}$, 宮田氏 ${ }^{78)}$, 角田氏 ${ }^{79}$ らの総説が発表されてい る。

A.C. Zettlemoyer 45) らはルチル形酸化チタンの表面 処理をシリカで行ない, 表面処理のシリカ量と湿潤熱の 関係等について研究し, シリカの処理量により顕著な变 化のある図-7 の関係を得ている。 $\mathrm{N}_{2}$ 表面積を用いた場 合と $\mathrm{H}_{2} \mathrm{O}$ 面積を用いた場合では，湿潤熱の値に大きな 変動を認めている。図-7 からシリカ処理 $15 \%$ では水蒸 気に対してポーラスであるが，窒素に対してはポーラス

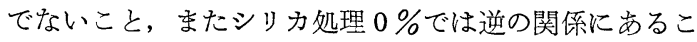
とが理解出来る。

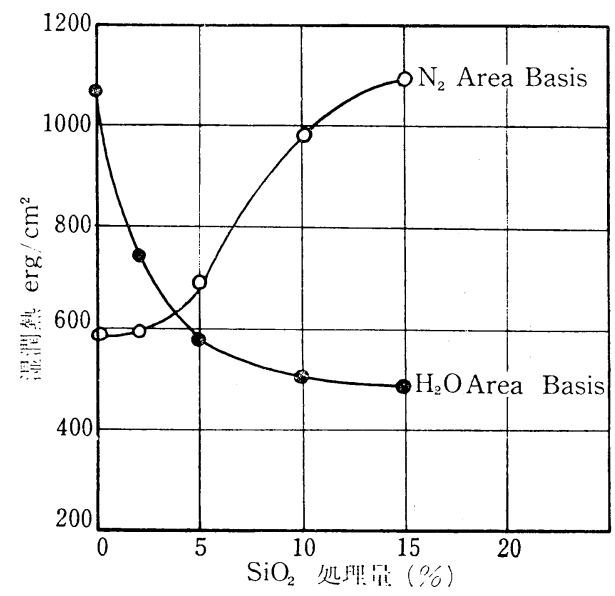

図-7 酸化チタンの $\mathrm{SiO}_{2}$ 処理量と潤潤熱

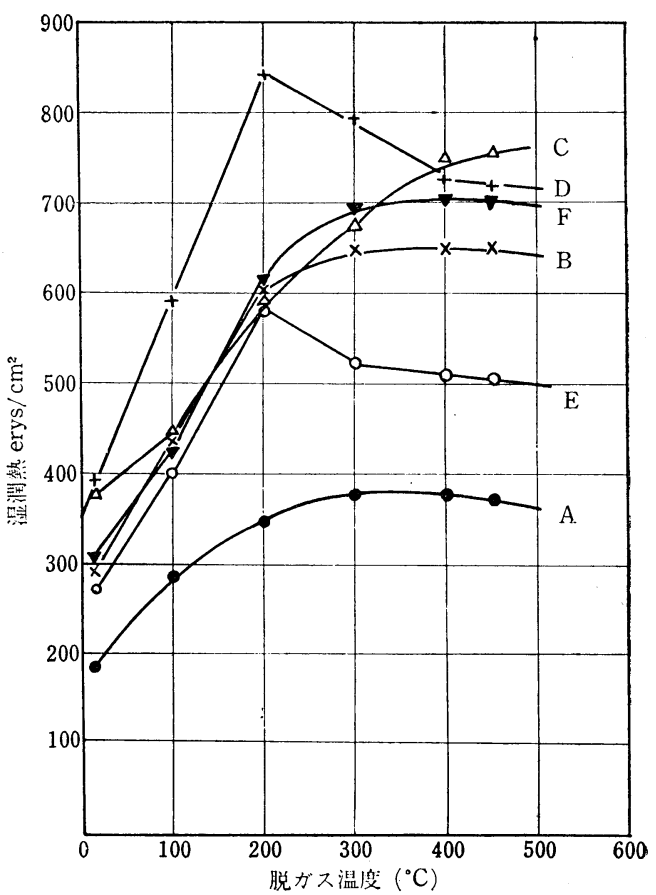

図-8 酸化チタンの表面処理と湿潤熱の関係

K. P. Herrington ${ }^{76)}$ らは表-7に示したよらなルチル形 酸化チタンの表面処理を行い, 湿潤熱の測定を行なって いる。脱ガス温度を変化させ湿潤熱を測定すると, 図-8 に示すように $\mathrm{Al}_{2} \mathrm{O}_{3}$ 単独処理のものは単純に增加の傾向 を示しているが, $\mathrm{SiO}_{2}+\mathrm{Al}_{2} \mathrm{O}_{3}$ 処理のものは $200^{\circ} \mathrm{C}$ 付近 に最大值を示し, $300^{\circ} \mathrm{C}, 400^{\circ} \mathrm{C}$ と減少している。これ は $\mathrm{Al}_{2} \mathrm{O}_{3}, \mathrm{SiO}_{2}$ の含水物の系で反応が起こり, $\mathrm{Si}-\mathrm{O}-\mathrm{Al}$ 結合が生成するためであろらと説明している。これは表 面処理剤の熱的変化を示するのとして, 物性と関連して 興味ある問題である。

表面処理を行なった酸化チタンの粒子表面は物性的に 最早酸化チタンではなく, 処理された新たな表面として の物理化学的性質を示するのである。塩素法, 硫酸法い ずれの方法によって調製された酸化チタンであっても， 同一処理を施されたものは類似した物理化学的性質を示 すことが，湿潤熱の測定から云われている。もともと酸 化チタンなど金属酸化物の粒子表面は通常単分子の水酸 化物層で和和われており, 湿潤熱の測定から高温で脱気 した粒子表面にも $\mathrm{OH}$ 基が存在して打り， $350^{\circ} \mathrm{C}$ で脱気 したものでも吸着した水が検出されている。表面処理に より試料表面の $\mathrm{OH}$ 数は変化するが, ぬれに対する顔料

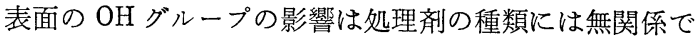
ある。それは図-9に示したように $\mathrm{OH}$ グループ数に対 する湿潜熱をプロットすれば直線関係にある事実 ${ }^{80}$ から。 


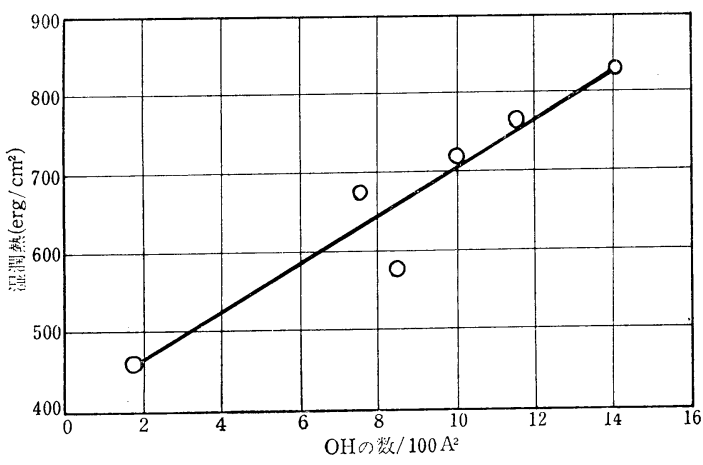

図-9 酸化チタンの表面の $\mathrm{OH}$ の数と湿潤熱

\section{も理解出来る。}

\section{3 分散媒中における顔料表面の荷電}

塗料，インキ等の溶液系に和ける顔料の分散，凝集等 を考える場合に顔料粒子の荷電を無親することの出来な

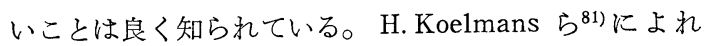
ば非極性液体中での分散が荷電によらず，吸着分子層の 保護作用で安定化するのは径 $100 \AA$ 以下の微粒子であ

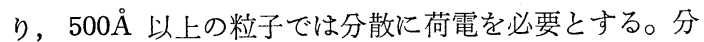
散粒子の荷電を考慮なしに溶液系に和ける分散, 浮き, 色分れ等の諸問題を論ずることは出来ない。非水系に拉 ける粒子の分散, 凝集, 荷電の諸問題については北原 氏82) 83) 84)の解説がある。

表面処理と荷電の問題及び実際面に和ける二, 三の例 を拾ってみることとする。 M. J. B. Franklin(5),86) は酸 化チタンについて $\mathrm{Al}_{2} \mathrm{O}_{3}$ あるいは $\mathrm{Al}_{2} \mathrm{O}_{3}+\mathrm{SiO}_{2}$ (いずれ も含水物）の表面処理を処理量と変化させて行ない,

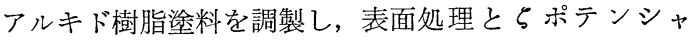
ル, 塗膜のいんぺい力の関係等の研究を行なっている。 $\mathrm{Al}_{2} \mathrm{O}_{3}$ の処理量と $\zeta$ ポテンシャルの関係については図10 の結果を得て和り, $\mathrm{Al}_{2} \mathrm{O}_{3}$ 処理量の增加につれて ポテンシャルは十側に増大して括り,これは樹脂の性質 の変化に関係なく同じ傾向を示している。らポテンシャ ルと塗膜のいんペい力の関係については, 図-11 の強い 相関のある結果を得ている。

清野氏87)によれば酸化チタンの水中に打汗る荷電の定 性的関係は表-8, 表-9 の通りである。 $\mathrm{TiO}_{2}$ 含水物処理

表-8 酸化チタン顔料の水中の荷電

\begin{tabular}{ccc|c}
\hline \multicolumn{2}{c|}{ 酸化チタンの表面処理 } & 荷 & 電 \\
\hline 処 & 理 & 乙 & -- \\
$\mathrm{A} 1$ & 処 & 理 & + \\
$\mathrm{Si}$ & 処 & 理 & --- \\
$\mathrm{Ti}$ & 処 & 理 & - \\
\hline
\end{tabular}

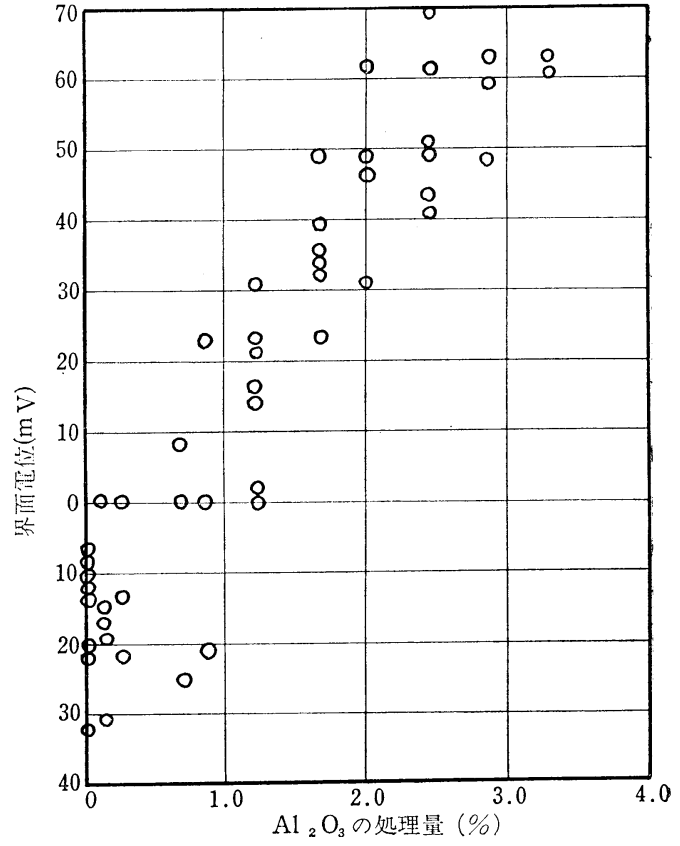

図-10 酸化チタンの $\mathrm{Al}_{2} \mathrm{O}_{3}$ 処理量と界面電位の関係

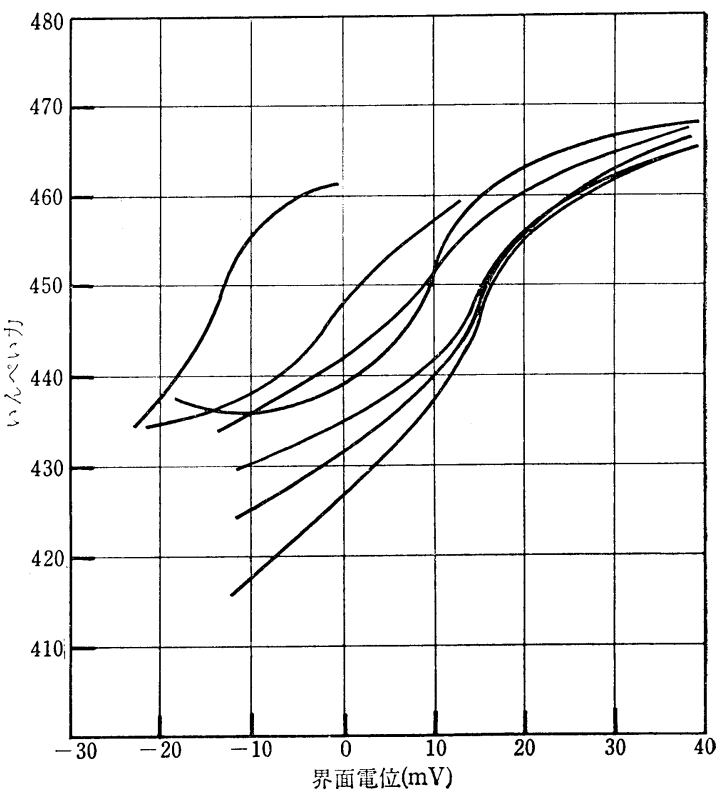

図-11 界面電位といんペい力の関係

は水中荷電にはほとんど無関係であるが, $\mathrm{Al}_{2} \mathrm{O}_{3} \cdot n \mathrm{H}_{2} \mathrm{O}$ の等電点は 9.1 付近といわれており，そのため $\mathrm{Al}_{2} \mathrm{O}_{3}$ 含水物処理により酸化チタンは $\mathrm{pH}$ の高い方向に等電点 が移行した。逆に $\mathrm{SiO}_{2} \cdot n \mathrm{H}_{2} \mathrm{O}$ の等電点は 2.5 あるいは 3.7 であり $\mathrm{SiO}_{2}$ 含水物処理により, 顔料の等電点を $\mathrm{pH}$ 
色材,

49 (1976)

表-9 酸化チタン顔料の荷電

\begin{tabular}{|c|c|c|c|c|}
\hline \multirow{2}{*}{$\begin{array}{l}\text { 酸化チタンの } \\
\text { 表 面 処 理 }\end{array}$} & \multirow{2}{*}{$\mid \begin{array}{c}\text { アクリル } \\
\text { 塗料中 }\end{array}$} & \multicolumn{3}{|c|}{ 水 } \\
\hline & & $\begin{array}{l}\mathrm{pH}=5 \\
(\text { 酢酸) }\end{array}$ & $\mathrm{pH}=7$ & $\begin{array}{c}\mathrm{pH}=9 \\
(\text { アンモニア) }\end{array}$ \\
\hline 処理なし & \pm & \pm & -- & -- \\
\hline $\mathrm{Al} \cdot \mathrm{Ti}$ 処 理 & ++ & ++ & \pm & $\pm \sim-$ \\
\hline $\mathrm{A} 1 \cdot \mathrm{Si} \cdot \mathrm{Ti}$ 処理 & + & + & - & - \\
\hline $\mathrm{Al} \cdot \mathrm{Si}$ 処 理 & + & + & - & - \\
\hline $\mathrm{A} 1 . \mathrm{Si} \cdot \mathrm{Ti}$ 処理 & - & + & - & --- \\
\hline
\end{tabular}

$\mathrm{S}: \underline{\mathrm{Si}}$ 処理量が多いことを示す。

の低い方向に移行させている。このように顔料の表面処 理により荷電のコントロールの出来ることは, 顔料工学 的に意義の大きいことで興味のある問題である。エマル ション塗料用酸化チタンは $\mathrm{SiO}_{2}$ 含水物の処理量を多く して pH 7〜9 の範囲に打ける水中分散性を向上させる ように製造されているものもある。

塗料に打ける色分れ現象について分散系中の顔料粒子 の荷電の影響の大きいことも理解出来る。橋爪氏 ${ }^{88)}$ は 表-10 に示したような各種のアルキドメラミン塗料中 に和けるフタロシアニンブルーと酸化チタンの色分れ性 と荷電の関係について研究しているが，次のような明白 な結果が得られている。すなわら各樹脂共通に荷電の大 きいものが荷電の符号に関係なく，色分れ性が良好であ る。

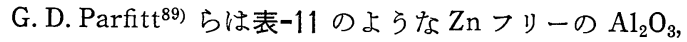
$\mathrm{SiO}_{2}$ 表面処理の酸化チタンを調製し, 電気泳動を利用 して表面処理の程度による PZC (Point of Zero Charge) の変化を検討した。図-12 は試料 2 についての電気泳動 の測定例であり， $\mathrm{pH}$ に対する電気泳動移動度のプロッ トの形は粒子に関連した電気二重層の特性を現してお り，明らかに PZZ (Point of Zero Zeta Potential) が
表-11 酸化チタンの表面処理と表面積

\begin{tabular}{|c|c|c|c|c|}
\hline \multirow{2}{*}{$\begin{array}{cc}\text { 顔 } & \text { 料 } \\
\left(\begin{array}{ll}\text { 酸 } & \text { 化 } \\
\text { チタン }\end{array}\right)\end{array}$} & \multicolumn{2}{|c|}{ 表面処理量 $(\%)$} & \multirow{2}{*}{$\begin{array}{c}\text { 表面処理 } \\
\mathrm{Al}_{2} \mathrm{O}_{3} \text { の割合 }\end{array}$} & \multirow{2}{*}{$\begin{array}{c}\text { 表 面 積 } \\
\mathrm{m}^{2} \mathrm{~g}^{-1}\end{array}$} \\
\hline & $\mathrm{Al}_{2} \mathrm{O}_{3}$ & $\mathrm{SiO}_{2}$ & & \\
\hline 1 & 0.55 & 1.88 & 0.23 & 8.4 \\
\hline 2 & 0.97 & 1.86 & 0.34 & 8.5 \\
\hline 3 & 1.75 & 1.84 & 0.49 & 10.4 \\
\hline 4 & 2.16 & 1.84 & 0.54 & 11.7 \\
\hline 5 & 2.18 & 0.98 & 0.69 & 10.9 \\
\hline 6 & 2. 14 & 0.56 & 0.80 & 9.3 \\
\hline 7 & 2.20 & 0.15 & 0.90 & 9.2 \\
\hline
\end{tabular}

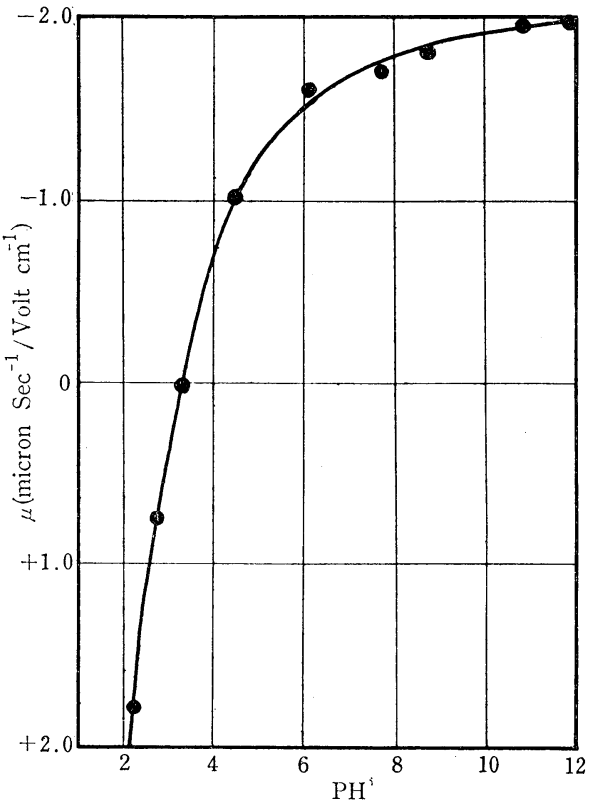

図-12 酸化チタンの $\mathrm{pH}$ によ電気泳動移動度の变化

表-10 各種アルキドメラミン塗料中に括けるフタロシアニンブルーと酸化チタンとの色分れ性と荷電

\begin{tabular}{|c|c|c|c|c|c|c|c|c|c|c|c|c|c|c|c|}
\hline & \multirow{2}{*}{\multicolumn{2}{|c|}{$\begin{array}{l}\text { 市 販 混 合 } \\
\text { クリヤーA }\end{array}$}} & \multirow{2}{*}{\multicolumn{2}{|c|}{$\begin{array}{l}\text { 市販 混合 } \\
ク リ+ー B\end{array}$}} & \multirow{2}{*}{\multicolumn{2}{|c|}{$\begin{array}{l}\text { 市肘 混 合 } \\
\text { クルーーC }\end{array}$}} & \multicolumn{4}{|c|}{$133-60+J-820$} & \multicolumn{4}{|c|}{$1307+J-820$} \\
\hline & & & & & & & & \multicolumn{2}{|c|}{ アルキド先練 } & \multicolumn{2}{|c|}{ 混 合 練 } & \multicolumn{2}{|c|}{ アルキド先練 } & \multicolumn{2}{|c|}{ 混 合 練 } \\
\hline & & 荷電 & $\begin{array}{l}\text { 色分れ } \\
\text { 性 }\end{array}$ & 荷電 & \begin{tabular}{|l|} 
色分れ \\
性
\end{tabular} & 荷電 & \begin{tabular}{|l} 
色分れ \\
性
\end{tabular} & 荷電 & \begin{tabular}{|l} 
色分れ \\
性
\end{tabular} & 荷電 & \begin{tabular}{|l|} 
色分れ \\
性
\end{tabular} & 荷電 & $\mid \begin{array}{l}\text { |色分れ } \\
\text { 性 }\end{array}$ & 荷電 & $\begin{array}{l}\text { 色分れ } \\
\text { 性 }\end{array}$ \\
\hline $\mathrm{TiO}_{2}$ & ( $\mathrm{R}$ 形) & + & & - & & ++ & & + & & + & & + & & + & \\
\hline \multirow{6}{*}{$\begin{array}{ll}7 & フ ゙ \\
タ & ル \\
\square & 1 \\
\ddot{y} & \\
> & \\
= & \\
\text { V } & \end{array}$} & $\alpha_{1}$ & + & 3 & + & 3 & +++ & 5 & +++ & 3 & +++ & 3 & ++ & 3 & +++ & 3 \\
\hline & $\alpha_{2}-\mathrm{P}$ & ++ & 5 & ++ & 1 & +++ & 5 & $++t$ & 5 & +++ & 5 & +++ & 5 & +++ & 5 \\
\hline & $\alpha_{3}-\mathrm{N}$ & - & 1 & - & 5 & - & 1 & - & 1 & - & 1 & - & 1 & - & 1 \\
\hline & $\beta_{1}$ & + & 1 & + & 1 & + & 1 & + & 1 & + & 1 & + & 1 & + & 1 \\
\hline & $\beta_{2}-\mathrm{P}$ & ++ & 5 & ++ & 1 & $++t$ & 5 & +++ & 5 & +++ & 5 & +++ & 5 & +++ & 5 \\
\hline & $\beta_{3}-\mathrm{N}$ & - & 1 & --- & 5 & - & 1 & - & 1 & - & 1 & - & 1 & & 1 \\
\hline
\end{tabular}

色分れ性 5: 完全分散 3:やや色分れ女り 1:色分れ顕著 


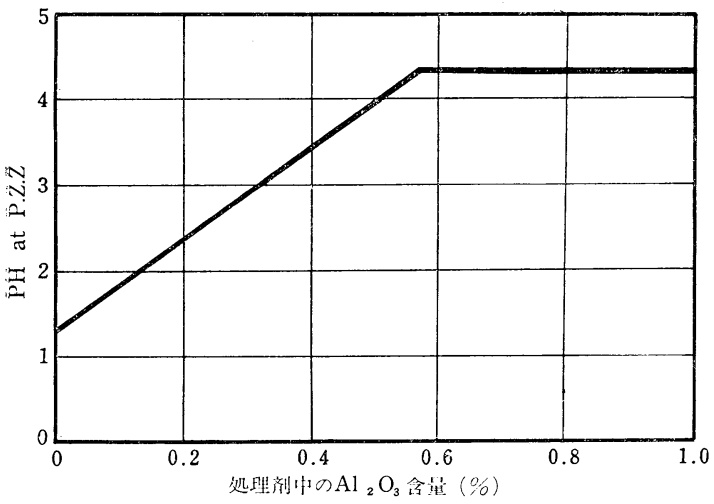

図-13 酸化チタン処理剤中のアルミナ含量と P.Z.Z. での $\mathrm{pH}$ 変化との関係

示されている。また図-13からは表面処理酸化物の PZC が，表面処理剤中の $\mathrm{Al}_{2} \mathrm{O}_{3}$ 量に直接関連することが理解 出来る。

\section{4 顔料固体表面における溶質の吸着現象}

塗料，インキ等の顔料分散の溶液系に拈ける顔料の分 散安定性は前にも触れたように, 界面電位と顔料表面に おける樹脂等の吸着層の立体障害効果の二者が大きく関 与することはよく知られている。この問題だけでなく, 被塗物への密着性, 塗膜中の分散性, 塗膜の機械的諸物 性への影響, あるいは電着塗装における樹脂と顔料の共 通性，塗料の色分れ現象など顔料工学的実際面からきわ めて大事なことであり，また溶液系に扣いて固体表面と 溶媒や溶質との間に働く相互作用はどんな性質のもの か。乙か子顔料の表面処理と吸着の関係は変化に富み, 物理化学的にも興味のある問題であり多くの研究がなさ れている。

A. F. Sherwood $5^{90)}$ はアルキド樹脂の官能基を代表 する純粋化合物（ステアリン酸，ステアリルアルコー ル，オンイン酸等）の酸化チタンへの吸着を等温線の型 および顔料一吸着質複合体の赤外線分光分析により調べ ている。図-14 は酸化チタンの表面処理の有無と酸化于 タンの乾燥度合と, ベンゼン溶液中に拈けるステアリン 酸の吸着を示したものである。 $\mathrm{Zn}, \mathrm{Al}, \mathrm{Si}$ の表面処理 を行なったものは乾燥度合により大きな吸着量の相違を 示すが，未処理のものは乾燥度合に関係なく同一の吸着 量を示している。また図-15 はステアリン酸を吸着した 酸化チタンの赤外線分析の結果であるが，表面処理の有 無による吸着機構の相違が現れている。 $\mathrm{Al}, \mathrm{Si}, \mathrm{Zn}$ 処 理を施したものは振動数 1,540 に，末処理のものは 1,700 に強い吸収がある。前者は $\mathrm{Zn}, \mathrm{Al}$ と $\mathrm{COOH}$ 基 のイオン結合であり, 後者は酸化チタン表面の $\mathrm{OH}$ 基と

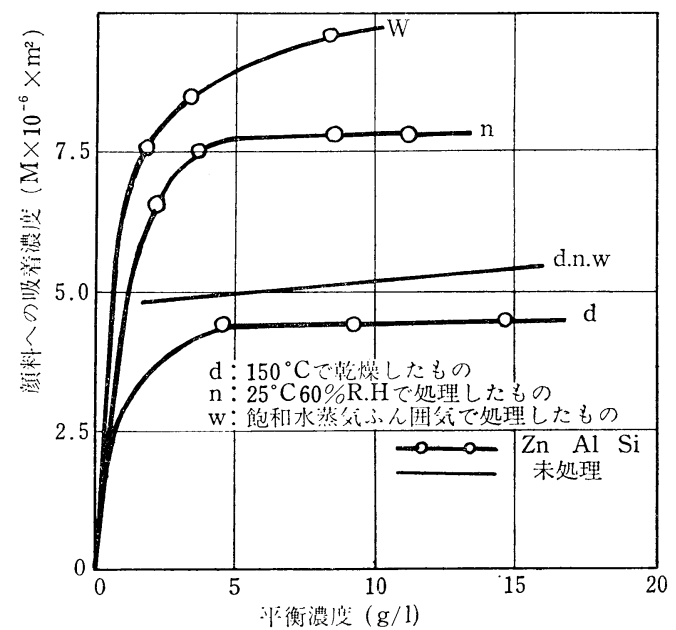

図-14 $\mathrm{TiO}_{2}$ に势けるステアリン酸の吸着 (ベンゼン溶液)

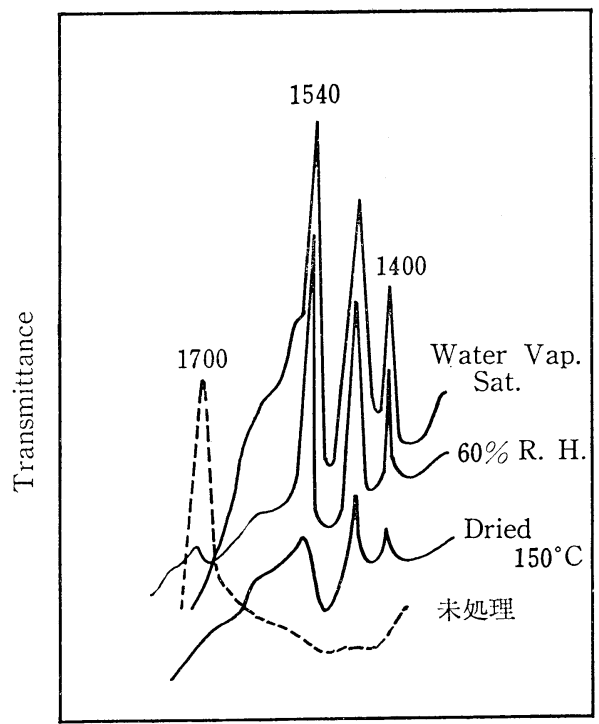

Frequency

図-15酸化チタンに和けるステアリン酸の吸着の赤 外線吸収スペクトル

ステアリン酸の $\mathrm{COOH}$ 基との水素結合である。このよ らに同ビステアリン酸の吸着でも表面処理の有無によ り, 吸着機構の異なることはまことに興味ある現象であ る。この例のように赤外線分光分析による顔料の表面状 態の観察は有効な手段であり, 顔料と媒体との相互作用 の情報を得ることが出来，媒体に対する顔料表面のあり 方についての知見を得ることが出来る。このような吸着 機構の解明は顔料表面処理を積極的に進める参考となろ 5。 
表-12 樹脂と溶剤の吸着

\begin{tabular}{|c|c|c|c|c|c|}
\hline 顔料 & $\begin{array}{l}\text { 樹 脂 の } \\
\text { 吸 着 } \\
\mathrm{mg} / \mathrm{g} \\
\mathrm{TiO}_{2}\end{array}$ & $\begin{array}{c}\text { 溶 剂 } \\
\text { の } \\
\text { 吸 } \\
\text { mg } / \mathrm{g} \\
\mathrm{TiO}_{2}\end{array}$ & $\begin{array}{c}\text { 顔 料 の } \\
\text { 表 面 積 } \\
\mathrm{m}^{2} / \mathrm{g}\end{array}$ & $\begin{array}{c}\text { 樹 脂 の } \\
\text { 吸 着 } \\
\mathrm{mg} / \mathrm{m}^{2}\end{array}$ & $\begin{array}{l}\text { 吸 着 層 } \\
\text { における } \\
\text { 溶剂/樹脂 }\end{array}$ \\
\hline A & 27.6 & 152.0 & 16.5 & 1. 67 & 5.5 \\
\hline B & 23.3 & 48.9 & 11.5 & 2. 01 & 2. 1 \\
\hline $\mathrm{C}$ & 13.1 & 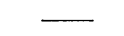 & 17.3 & 0.76 & \\
\hline
\end{tabular}

顔料の表面処理

$\mathrm{A}: \mathrm{Al}_{2} \mathrm{O}_{3} \cdot n \mathrm{H}_{2} \mathrm{O}$ (主) $+\mathrm{TiO}_{2} \cdot n \mathrm{H}_{2} \mathrm{O}$

B : $\mathrm{Al}_{2} \mathrm{O}_{3} \cdot n \mathrm{H}_{2} \mathrm{O}$ (主) $+\mathrm{SiO}_{2} \cdot n \mathrm{H}_{2} \mathrm{O}+\mathrm{TiO}_{2} \cdot n \mathrm{H}_{2} \mathrm{O}$

C : $\mathrm{SiO}_{2} \cdot n \mathrm{H}_{2} \mathrm{O}$

表-13 いえペい力と $\zeta$ 電位との関係（顔料 B ）

\begin{tabular}{c|c|c|c}
\hline 樹 脂 & 酸 価 & $\begin{array}{c}\text { いんぺい力 } \\
\mathrm{H}_{3} \text { に対する減少值 }\end{array}$ & $\begin{array}{c}\zeta \text { 電 位 } \\
\mathrm{mV}\end{array}$ \\
\hline $\mathrm{H}_{1}$ & 19.7 & $18 \%$ & 77.6 \\
$\mathrm{H}_{2}$ & 9.4 & $6 \%$ & 70.8 \\
$\mathrm{H}_{3}$ & 3.8 & & 66.1 \\
\hline
\end{tabular}

K. Goldsbrough ら ${ }^{91)}$ は表面処理の異なる酸化チタン を調製し，樹脂，溶剤の吸着測定やリノレン酸を使用 し, 油長 $70 \%$ ，無水フタール酸 $19.9 \%$ のアルキド樹 脂を合成し，塗料を調製し，いんペい力ととポテンシ ヤルの関係を測定している。表-12，表-13 にそれぞれ の結果を示す。これによれば樹脂，溶剤（白灯油）の吸 着量は明らかに表面処理により異なり, $\mathrm{TiO}_{2} \mathrm{~g}$ 当たり では $\mathrm{Al}_{2} \mathrm{O}_{3}$ 含水物を主としたものと $(\mathrm{A}, \mathrm{B}) \mathrm{SiO}_{2}$ 含水 物を主としたもの（C）とは大きく異なるが，表面積は A，Cが大きい。しかし，処理剤の定量的表現がなく敛 密な検討が出来ない。顔料 Bについての酸価を変化させ てのらポテンシャルについては, 酸価と相関があり, 酸 価の大きいものほどらポテンシャルが大きい。いんペい 力は酸価の大きいものほど小さい傾向を示している。顔 料に対する樹脂の吸着量の測定は $\mathrm{C}^{14}$ ラベルのリノリン 酸を使用したアルキド樹脂を合成して，放射線トレーサ 一法を使用した。その結果を図-16 に示すが表面処理剤 の相違により，明らかに吸着量の変化が現れている。

酸化チタンは $\mathrm{Al}_{2} \mathrm{O}_{3} \cdot n \mathrm{H}_{2} \mathrm{O}$ 処理することにより, ア ルキド樹脂中の分散性がよくなるが，これについて M. B. Alpert ら ${ }^{92)}$ は図-17 のよらな機構によるとしてい る。すなわち酸化チタンに表面処理した $\mathrm{Al}_{2} \mathrm{O}_{3} \cdot n \mathrm{H}_{2} \mathrm{O}$ が，アルキド樹脂中の有機残基と反応して $\mathrm{A} 1$ 塩を作 り, 電離して酸化チタン表面に電気二重層を形成し, 酸 化チタンにやの界面電位を生じ分散性がよくなるといわ れている。この実験において塗膜の光沢に対する顔料の 水分効果について試験し，水分の多い場合に光沢のよい ことを確かめている。また表面処理したものを熱処理す

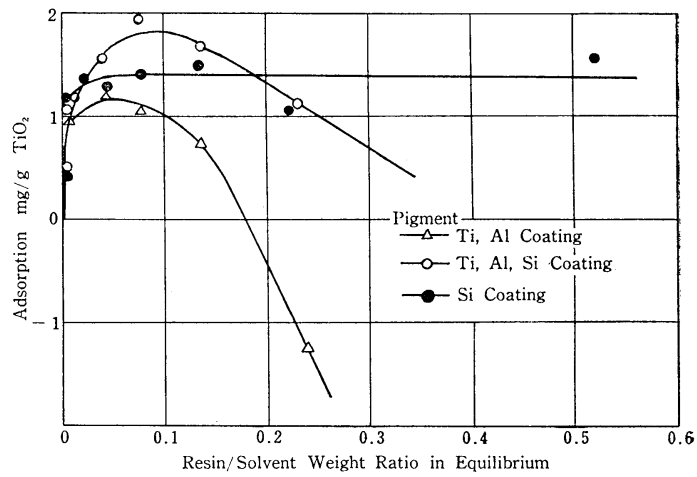

図-16 酸化チタンの表面処理とアルキド樹脂の吸着

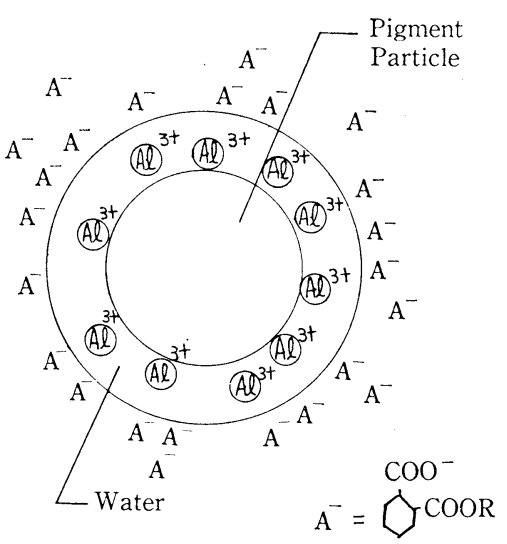

図-17 アルキド樹脂中の酸化チタン粒子

ると, 表面処理アルミナ水和物の活性を減じ, 光沢のレ ベルは順次減少する結果を得ている。この例でも顔料の 表面状態と物性のデリケートな関係が理解出来る。

\section{5 表面処理とその他の諸物性}

本田氏 ${ }^{93)}$ は酸化チタンについて, $\mathrm{Al}_{2} \mathrm{O}_{3}, \mathrm{SiO}_{2}, \mathrm{TiO}_{2}$, の含水物による表面処理と電着塗装の関係について次の ように述べている。アクリル樹脂（特性の樹脂）のビヒ クル中での分散は $\mathrm{TiO}_{2} \cdot n \mathrm{H}_{2} \mathrm{O}$ や $\mathrm{SiO}_{2} \cdot n \mathrm{H}_{2} \mathrm{O}$ 処理は分 散性を良くするが, $\mathrm{SiO}_{2} \cdot n \mathrm{H}_{2} \mathrm{O}$ 処理のものは電着量が 少なく且つ塗膜の光沢も低く, ニズ肌になった。 $\mathrm{Al}_{2} \mathrm{O}_{3}$. $n \mathrm{H}_{2} \mathrm{O}$ 処理のものは電着量も多く, 塗膜は高い光沢を示 した。電着塗料用として $\mathrm{SiO}_{2} \cdot n \mathrm{H}_{2} \mathrm{O}$ 処理はあまり望ま しくない。 $\mathrm{TiO}_{2} \cdot n \mathrm{H}_{2} \mathrm{O}$ 処理も $\mathrm{SiO}_{2} \cdot n \mathrm{H}_{2} \mathrm{O}$ 処理に比較 的類似した挙動を示しており, 電着性, 塗膜性能の面か ら制限されるとしている。 $\mathrm{Al}_{2} \mathrm{O}_{3} \cdot n \mathrm{H}_{2} \mathrm{O}$ 処理は電着性と 塗膜状態が良いが，塗料中の分散性がよくない。また沈 降ケーキは多いが再分散は比較的容易である。このよう に電着塗料においては酸化チタンの表面処理組成によっ て支配されることが多いが，一方樹脂の組成によっても 
表-14 酸化チタンの表面処理と分散性（非水系）

\begin{tabular}{|c|c|c|c|c|c|c|c|c|c|}
\hline \multirow{2}{*}{$\begin{array}{c}\text { 表面処理 } \\
\mathrm{Al}_{2} \mathrm{O}_{3} / \mathrm{Al}_{2} \mathrm{O}_{3} \\
+\mathrm{SiO}_{2}\end{array}$} & \multicolumn{9}{|c|}{ 非 水 系 媒 体 (分散度\%) } \\
\hline & キシロール & $\mathrm{CCl}_{4}$ & 酶酸エチル & $\begin{array}{c}n-\text { ブタ } \\
\text { ノール }\end{array}$ & アセトン & DMF & メタノール & $\begin{array}{c}\text { エチレン } \\
\text { グリコール }\end{array}$ & DMSO \\
\hline 0.3 & 0 & 0 & 0 & 50 & 72 & 85 & 70 & 95 & 80 \\
\hline 0.4 & 0 & 0 & 0 & 0 & 20 & 90 & 65 & 95 & 80 \\
\hline 0.8 & 0 & 0 & 0 & 80 & 0 & 80 & 95 & 95 & 85 \\
\hline
\end{tabular}

表-15 酸化チタンの表面処理と分散性（水）

\begin{tabular}{|c|c|c|c|c|c|c|c|c|c|c|c|}
\hline $\mathrm{pH}$ & \multicolumn{5}{|c|}{ 分 } & 散 & \multicolumn{3}{|c|}{ 度 } & & \\
\hline $\begin{array}{l}\text { 表面 } \\
\text { 処理 }\end{array}$ & 2 & 3 & 4 & 5 & 6 & 7 & 8 & 9 & 10 & 11 & 12 \\
\hline $\mathrm{Al}_{2} \mathrm{O}_{3}$ & (a) & (a) & (a) & $\times$ & $\times$ & $\times$ & $\times$ & $\times$ & (2) & (a) & (a) \\
\hline $\mathrm{Al}_{2} \mathrm{O}_{3}>\mathrm{SiO}_{2}$ & (2) & (2) & (a) & $x$ & $x$ & $\times$ & $\times$ & $\times$ & (a) & (a) & (a) \\
\hline $\mathrm{Al}_{2} \mathrm{O}_{3}<\mathrm{SiO}_{2}$ & $x$ & $x$ & $\Delta \sim 0$ & 0 & (a) & (a) & (a) & (a) & (a) & (a) & () \\
\hline
\end{tabular}

(): 分散度 $\bigcirc$ : 分散やや良 $\triangle$ : 分散不十分 $\times$ : 分散しない

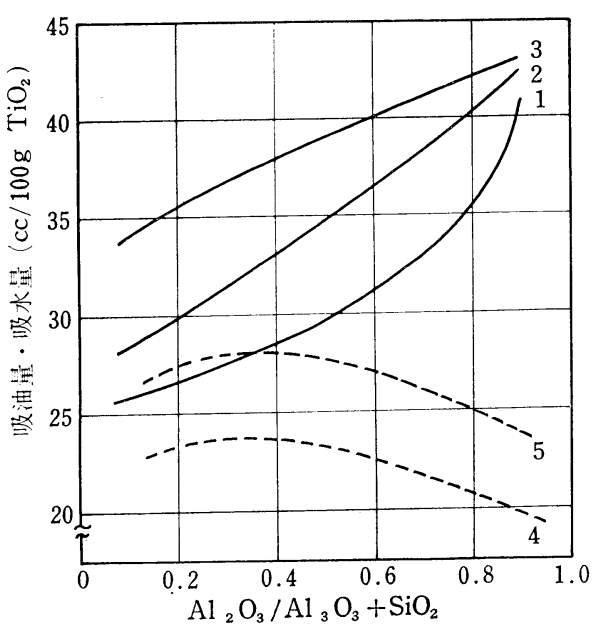

図-19 $\mathrm{Al}_{2} \mathrm{O}_{3} / \mathrm{Al}_{2} \mathrm{O}_{3}+\mathrm{SiO}_{2}$ と吸油量拉よび吸水量 1. 全処理量 $1 \% 2$. 全処理量 $3 \%$

3. 全処理量 $6 \%$. 4 . $1 \%$

5. $" 113 \sim 6 \%$

— 吸水量 ……吸油量

著しく影響をうけるため，実際の場合には可成りの選択 のむずかしさがあろう。

非水系媒体中の分散に関しては年), $\mathrm{Al}_{2} \mathrm{O}_{3} / \mathrm{Al}_{2} \mathrm{O}_{3}+\mathrm{SiO}_{2}$ の比が表-14 に示したように，キシロール， $\mathrm{CCl}_{4}$, 酢酸 エチルはこれの比に関係なく分散不良であるが，n-ブタ ノール，アセトンはこれの比により大きく変化する。 また DMF，メタノール，エチレングリコール，DMSO はいずれもこれの比に大きく関係はなく，よい分散を示 している。

水分散性は $\mathrm{pH}$ により大きく変化するが, $\mathrm{SiO}_{2} \cdot n \mathrm{H}_{2} \mathrm{O}$
の処理量が $\mathrm{Al}_{2} \mathrm{O}_{3} \cdot n \mathrm{H}_{2} \mathrm{O}$ 処理量より多いものは分散性の 良好な $\mathrm{pH}$ 領域が広い。この関係を表-15 に示す。

また吸油量, 吸水量の関係については図-18に示した ように明らかに，この比の変化に対して互に相反する傾 向を示している。

このように表面処理剤の種類による効果の相違のある ことは明らかであるが，また表面処理剤を組み合わせて 使用した場合, 処理剂それぞれの比率によって物性の変 化することも見のがせない。H. Rechmann ${ }^{64)}$ は表面処 理の異なる種々な酸化チタンについて, 種々の溶剂中及 び水溶性樹脂中での挙動について研究を行なった。その 結果顔料の泳動特性は酸化チタンの結晶形でなく, 表面 処理の影響が支配であることを示し，しか子表面処理剤 の絶対量に基づくものではなく, $\mathrm{Al}_{2} \mathrm{O}_{3} / \mathrm{SiO}_{2}$ の比，すな わら

$$
V=\log \frac{\mathrm{Al}_{2} \mathrm{O}_{3}}{\mathrm{SiO}_{2}}
$$

$\left(\mathrm{Al}_{2} \mathrm{O}_{3}, \mathrm{SiO}_{2}\right.$ は含水物で $\mathrm{TiO}_{2}$ に対する重量百分率 $)$

のVによるものであることを述べている。

表面積が増大し，しかも親水性物質で表面処理を行な った場合には，顔料の水分の増加することがしばしばあ る。たまたま手もとにある A.S.T.M のルチル形酸化 チタンの水分（厳密には $100 \sim 105^{\circ} \mathrm{C}$ での減量で水分と 他の揮発性物質）についての規格では，表面処理なしの ものはいずれも上限が $0.5 \%$ (1948), 0.7\% (1968),

0.7\%（1970）になっているが，表面処理を施したるの では $0.5 \%$ (1948), $1.25 \%$ (1968), 1.5\% (1970) と 変遷しており，酸化チタンの製造技術の進歩と品質の向 上とともに増大しているのは一見皮肉な現象である。し 
かし，これらの水分は新たな分野 (エマルション塗料) への銘柄の開発も理由としてあげられるが，一般に分散 性, 耐久性等の品質向上を図った結果の二次的現象であ り, 塗料, インキ等の実用面においては支障のない数值 である。

\section{6. 表面処理における問題点}

表面処理についていろいろ述べて来たように多くのメ リットがあり，広い角度から取り上げられているが，実 際行ならについてはいくつかの問題点もある。

（1）顔料の種類が多く，顔料の使用面が広く，また 表面処理の目的がバラエテイに富み，また塗料，インキ 等その一つ一つを取り上げてもその内容がきわめて多岐 にわたるために, 顔料の表面処理に厳密には普遍性がな く,ケースバイケースで最も適切な表面処理方法を設計 する必要がある。多面的な表面処理は実際問題として場 合により困難である。

（2）顔料は複雑な多成分系で使用される場合が多 く, 表面処理剤から思わぬトラブルを招来することもあ り, 使用面から広範囲に使用適性の確認が必要である。 場合により使用面で選択性の生ずることは表面処理を行 なった場合の欠点と云えよう。使用される条件と表面処 理された顔料との相互作用について，あらかじめ十分な る知見を得ておくことが必要と考えられる。特に表面活 性剤の類を使用する場合には，選択性の点について十分 なる検討が必要である。

（3）湿式で表面処理を行なら場合には 3.5 で述べた よらに同じ処理剤を使用しても，その処理方法によって 処理された顔料のミクロな表面状態は大いに変化があ り, その効果は顕著に相違するものである。単に経験に のみ頼ることなく積極的に進めるためには顔料表面にお ける物理化学的なミクロな思考が必要である。

（4）塗料,インキ等の溶液系に㧅いては顔料表面に おける溶質の吸着現象などは, 表面処理剂の相違により 異なり, 貯蔵安定性などレオロジカルな性質の変動の起 こることもある。また界面電位, 湿潤熱等基礎的な物理 化学的なミクロな思考の導入が期待されるが, 実際面に おいては余りにも多成分系で扱われる場合が多く，きわ めて複雑な問題であり経駼的に取扱われているのが実情 であろら。ある与えられた特定の系に和ける諸現象につ いて, これら基礎的思考に基ついて分析的に解明するこ とは出来ても, 普遍性を求めて解明してゆくことはきわ めて難解な分野であるように思われるが，今後の究明が 期待されるし，そらあることを願らものである。

（5）表面処理はその方法により経済的に可成りのコ
ストアップになる。酸化チタンの湿式法による表面処理 では，まず粉砕一分級一表面処理一洗浄一沪過一乾燥— 微粉砕一製品と云った長い工程となり, 設備的にも顔料 製造の全工程からみて可成り大きなものとなり，またラ ンニングコストも安くはない, 従って十分に表面処理効 果の期待出来る方法を選ばなければならない。またその. 効果と経済性について十分考える必要がある。

\section{7. 結诰}

顔料の表面処理は以上述べて来たようにきわめて多岐 にわたり，その全貌を述べることは，はなはだ困難であ， るが表面処理により表-3 に述べたような，いろいろな 角度からの顔料性の改質が可能であり, 顔料工学的に大 きなメリットが期待されまた技術的にも物理化学的に もはなはだ興味のある問題である。顔料関係の技術的動 向は特許などの情報でみる限り新規顔料の開発は少な く, 表面処理等により更に既存顔料に高度の顔料性を開 発しよらとする動きがあり，顔料界の一つの技術的動向 といらことが出来よう。また現在顔料は己にそうした表 面処理を施すことが常識化して来ているような技術レベ ルに到達しているといらことが出来よう。しかし現在実 際の表面処理技術は経験的手法に従っているものが多 く，ミクロな基礎的思考に基づいて開発されているすの は少ないのが実情であろう。6 項で述べたような難解な 問題点もあるが，これからの顔料の表面処理を発展させ るためには, 顔料固体表面の物性, 溶液系に打ける顔料 固体表面に䑙ける溶質の吸着, 界面電位, あるいはぬれ の問題等物理化学的基礎知識の総合的な解明が強く要望 されるものと思われる。未だ模索の段階で前途ほど遠し の感頻りなるものがあるが, 個々のデーターの集積はや がて境界領域の問題も埋められて, 個々の要素で構成さ れた総合的な美花の咲き初める日を期待することが出来 るものと思われる。

\section{文献（II）}

61）最新粉粒体プロセス技術集成, プロセス編 p. 229,（株) 産業技術センター（昭 49）

62）特公昭 40-9129

63）特公昭 48-29528

64） H. Rechmann : J. O.C.C. A, 48, 837 (1965)

65）特公昭 47-25130

66）特公昭 48-12853

67）特公昭 47-11587

68）特公昭 48-39213

69）特公昭 48-23178

70) R. Kroker, M. Schenider, K. Hamann : Progress in Organic Coating, 1, 23 (1972)

71）堀内正二郎：色材, 38, 100 (1965) 
72) $\quad$ " : " , 38, $110(1965)$

73) " : : , 38, 117 (1965)

74）岡崎 進, 菅野隆：日化, 1285 (1973)

75）宇津木弘, 西村成與, 加藤哲郎：日化, 1557 (1972)

76) K. D. Herrington, Y.K. Lui : J. Coll. Interface Sci., 34, 447 (1970)

77）森本哲雄：色材，37, 264 (1964)

78）宮田謙一：色材, 40, 223 (1967)

79）角田光雄：色材，36, 489 (1963)

80) F. B. Stieg: J. Paint Tech., 43, No. 561, 36 (1971)

81) K. Koelmans, J. H. G. Overbeek : Discussion of Faraday Soc., 18, 52 (1954)

82）北原文雄 : 色材，37，10（1964）

83) " : " , 38, 541 (1965)

84) " : " , 39, 465 (1966)
85） M. J. B. Frnklin : J. O.C. C. A., 51, 499 (1968)

86) M. J. B. Franklin, K. Galdsbrough, G. D. Parfitt, J. Peacock : J. Paint Tech., 42, 740 (1970)

87）清野 学：色材, 40, 163 (1967)

88）橋爪 清：塗装技術，6月増刊号（1966）

89) G. D. Parfitt, J. Ramsbotham : J.O.C.C.A., 54, 356 (1971)

90) A. F. Sherwood, S. M. Rybicka : J. O.C. C. A., 49, 648 (1966)

91) K. Goldsbroogh, J. Peacock : J.O.C.C.A., 54, 506 (1971)

92) M. B. Alpert, A. E. Jacobsen, P. B. Mitton : Ind. Eng. Chem. Prod. Res. Develop., 2, 264 (1963)

93）本田敬夫：塗装と塗料， p. 33（1969）

94）石原産業株式会社型録

\section{色 材 協 会 誌 Vol. 49 No. 3 (予告)}

報文

ポリハロゲン化有機顔料のハロゲン化度の低下を計る試み……………阪府立大学 松 岡 賢他 アゾ基を有するフタロン系顔料の研究…………………大日本インキ化学工業(株) 高 木 邦 彦他 塗装現場に抢いて自然乾燥型塗膜の乾燥硬化状態を測定する装置の開発

テーマ資 料（色材と表面処理） 日本ペイント(株) 山本隆他

表面処理剤の動向 日本ペイント(株) 渡 辺ともみ 表面処理鋼板 新日本製鉄(株) 田 中 忠 アルミニウム及びアルミニウム合金と表面処理 三菱アルミニウム(株）丸 山 礼二郎 